Silvio KOŠĆAK

Legrad

koscak.silvio@gmail.com
UDK 272-528-276.63

Izvorni znanstveni članak

Primljen: 25. svibnja 2019.

Prihvaćen: 9. listopada 2019.

\title{
TEOLOŠKO-ALEGORIJSKO TUMAČENJE NOĆNE SLUŽBE OFICIJA U LITURGIJSKOJ EKSPOZICIJI VILIMA DURANDA (1230. - 1296.) S NAGLASKOM NA ANTIFONE I PSALMODIJU
}

\begin{abstract}
Autor istražuje simbolizam i alegoriju u tumačenju oficija i obrednih gesta rimskog oficija 13. stoljeća u srednjovjekovnoj liturgijskoj ekspoziciji Rationale divinorum officiorum Vilima Duranda (1230. - 1296.), prvoj ne-biblijskoj tiskanoj knjizi. Peta knjiga, De divinis officiis, tumači kleru biskupije Mende raspored moljenja božanskog oficija. Durand se osvrće na razne liturgijske tradicije, ali oficij koji tumači pripada rimskome obredu. U prvom dijelu rada autor daje opći pregled teološko-alegorijskog tumačenja liturgijske ekspozicije nastale na vrhuncu pisanja ovakvih traktata, iz kojih su svećenici prije 14. stoljeća i bule Unam sanctam pape Bonifacija VIII. učili i usvajali nauk o Crkvi, i specifično znanje o svemu što se odvija tijekom liturgijskoga čina unutar liturgijskoga prostora. Tumačenje liturgijske prakse Durand temelji na povijesnoj, alegorijskoj, tropološkoj i anagoškoj egzegezi Svetoga pisma. Važnost Rationale divinorum officiorum nalazi se u broju izdanja nakon posljednje recenzije. Riječ je o četrdeset pet izdanja do 1501. g. te novih četrdeset i tri tijekom 16. stoljeća. Značaj Durandove ekspozicije je i u utjecaju na naraštaje teologa do Drugoga vatikanskoga koncila i liturgijske reforme koja mu je slijedila. U drugom dijelu rada autor istražuje simbolizam antifona i psalmodije u dijelu pete knjige s naslovom Quid sit officium. Treći dio rada istražuje značenja koja Durand dodaje noćnoj službi u dijelu pete knjige s naslovom $D e$ nocturnis, gdje ovaj molitveni dio dana povezuje s noćnom službom crkvene zajednice predkonstantinovskoga razdoblja.
\end{abstract}

Ključne riječi: Vilim Durand, Guilielmus Durandus, liturgijska ekspozicija, Rationale divinorum officiorum, antifona, psalam, noćna služba, alegorijsko tumačenje

\section{UVOD}

Na hrvatskomu govornome području djela Vilima Duranda nisu sustavno istraživana. Suvremena se istraživanja odnose na jezične posebnosti u prije- 
vodima Rationale divinorum officiorum (u nastavku teksta: $\mathrm{RDO}$ ) na ruski ${ }^{1} \mathrm{i}$ njemački jezik. ${ }^{2}$ U Brepolsovim izdanjima nalazimo kritičko izdanje RDO-a, a studije uz njega donose rasprave o Durandovim izvorima. ${ }^{3}$ Timoty Thibodeau priredio je prijevode dijelova traktata na engleski jezik ${ }^{4}$ istražujući i razinu originalnosti Durandova rada koja se krije u specifičnoj uporabi kanonskopravne literature i otačke teologije, uz pomoć kojih - kompiliranjem - stvara RDO. ${ }^{5}$ Uz to, istraživao je metodologiju Durandove biblijske egzegeze, ${ }^{6}$ razumijevanje transupstancijacije u RDO, ${ }^{7}$ kao i utjecaj kanonskoga prava na tekstove liturgijskih ekspozicija od 1100. do 1300 . god. ${ }^{8}$ Whitehead je istraživao srednjovjekovnu simboliku koju su autori liturgijskih priručnika, uz ostale i Durand, pridavali crkvenoj arhitekturi. ${ }^{9}$ Stephen Mark Holmes je istraživao i utjecaj ekspozicije na škotske reformatore, ${ }^{10}$ posebice se na jednome mjestu osvrćući na marginalije u primjerku RDO-a koji je posjedovao Cranmer, te utjecaj RDO-a na engleski anglikanizam. ${ }^{11} \mathrm{U}$ svomu drugome radu Holmes donosi zaključak da je Durandova ekspozicija primjer ekleziologije, teološkoga promišljanja o Crkvi prije pojave prvih zaokruženih eklezioloških traktata o Crkvi (lat. de ecclesia), koji nastaju nakon objavljivanja bule Unam sanctam pape Bonifacija VIII. 1302. godine (usp. HOLMES 2011). Značaj Durandove ekspozicije ističe Pietro Sorci, navodeći da je RDO 1498. godine koristio rimski pontifikalni ceremonijar Giovanni Burcardo za oblikovanje reda slavljenja (lat. ordo servandus) i rubrika misala, elemenata koji su nedostajali u dotad korištenim misalima (usp. SORCI 2007: 47).

Prikazano stanje istraživanja pokazuje da je RDO istraživan s različitih stajališta, a najčešće u okviru kritike teksta te sporadičnih povijesno-teoloških i povijesno-liturgijskih istraživanja. No, može se reći da RDO-ov teološki značaj nije ni u svjetskoj ni u domaćoj literaturi sustavnije istraživan. U okviru istraživanja predtridentskih brevijara, istražili smo Petu knjigu RDO-a (u nastavku teksta: RDO V) u kojoj Durand tematizira kompletan oficij u razdoblju

\footnotetext{
${ }^{1}$ V. ROMANOVA; ROMODANOVSKAJA 2012.

${ }^{2}$ V. BUIJSSEN 1966; THOMSON 1994.

${ }^{3}$ V. DURANTUS 1995; DURANTUS 1998; DURANTUS 2000.

${ }^{4}$ V. THIBODEAU 2010; DURAND 2010; DURAND 2013; DURAND 2015.

${ }^{5} \mathrm{~V}$. THIBODEAU 1992.

${ }^{6} \mathrm{~V}$. THIBODEAU 1993.

${ }^{7} \mathrm{~V}$. THIBODEAU 1996.

${ }^{8} \mathrm{~V}$. THIBODEAU 1997.

${ }^{9} \mathrm{~V}$. WHITEHEAD 2003.

${ }^{10} \mathrm{~V}$. HOLMES 2015.

${ }^{11} \mathrm{~V}$. HOLMES 2015.
} 
13. stoljeća. Budući da ni predtridentski brevijari nisu dolazili sa specifičnim ordo-om, odnosno rasporedom slavlja i kompletnim rubrikama koje bi govorile o liturgijskim gestama prilikom zajedničkoga moljenja oficija, kao ni misali koje je istraživao spomenuti Pietro Sorci, Durand je u ovom području vrijedan izvor istraživanja liturgije. Osim rasporeda slavlja, Durand donosi i vrijedan izvor za teološko-alegorijsko tumačenje koje je dodao tijeku oficija. U simbolici moljenja oficija, bez obzira na često paušalne zaključke donesene o srednjovjekovnoj crkvenoj zajednici i njezinim teolozima, Durand donosi sliku težnji koje je imala crkvena zajednica 13. stoljeća, ideale kojima se vodila, mjesta na kojima je bila usidrena i putevima reforme kojima se kretala. Kako bismo istražili teološko-alegorijsko tumačenje upisano u značenje obreda oficija, odabrali smo manji dio ovog opsežnoga djela, koji nam može dati uvid u Durandov značaj u istraživanjima srednjovjekovne liturgije i teologije općenito. Istraživački materijal za ovaj rad predstavljaju tri dijela RDO V: 2[4], 2[6] i 3,1-37, a analiziramo ih nakon prikaza Durandova života i njegove liturgijske ekspozicije RDO-a.

\section{VILIM DURAND I RDO U KONTEKSTU SREDNJOVJEKOVNE LITURGIJSKE EKSPOZITORSKE LITERATURE}

Vilim Durand rođen je 1230. ili 1231. u francuskome gradu Puymissionu u blizini Béziersa. Važno je ne zamijeniti ga s istoimenim nećakom koji ga je kasnije zamijenio na biskupskoj stolici biskupije Mende. Tako je kasnije dobio naziv »Durand Stariji «, ili »Durand iz Mende « - prema gradu u kojemu je kasnije bio biskup. ${ }^{12}$ Unutar crkvene hijerarhije francuskoga govornoga područja vršio je važne službe te je bio nositelj različitih crkvenih časti. Maquelonskim kanonikom postaje 1251., a od 1254. duhovnik je crkve u Narboni (usp. BUIJSSEN 1966: 15-24).

Prijelomni trenutak njegova života bio je odlazak na studij u Modenu, gdje od 1255. studira crkveno pravo. Tijekom pontifikata Klementa IV. (1265. 1268.) postaje kurijalni službenik u Rimu, vršeći službu generalnog auditora u kauzama apostolske palače (lat. audientia causarum sacri palatii), a ujedno je kapetan i upravitelj papinske države. Ovu posljednju službu ustanovio je papa Nikola III. kako bi one koje rimski prvosvećenik delegira vodili brigu o stvarima države u njegovo ime. Kao kapetan papinske države svoju službu je vršio

\footnotetext{
${ }^{12} \mathrm{U}$ našem radu ime istraživanog autora bilježimo hrvatskom inačicom imena, odnosno Vilim, a prezime inačicom Durand. Na mrežnim stranicama The Consortium of European Research Libraries (CERL) može se pronaći niz inačica bilježenja Durandova imena u literaturi. Usp. Durantis, Guilelmus, Mende, Bischof. URL: https://data.cerl.org/thesaurus/cnp01323088 (5. IV. 2019.).
} 
i u vrijeme pontifikata pape Martina IV. i Bonifacija VIII. Iako je bio u Rimu, papa Klement IV. imenuje ga kanonikom bez obveze rezidencije u Beawaisu i Narbonni. Kao član kurije u Rimu sudjelovao je u radu 14. općeg Drugoga lijonskoga koncila koji je sazvao papa Grgur X. Budući da je u to vrijeme bio poznat po djelu kanonsko-pravne tematike Speculum iudicale, uživao je veliko povjerenje koncilskih otaca, što je posebno vidljivo iz njegova rada na redakciji koncilskih dokumenata (usp. BUIJSSEN 1966: 15-24).

Nakon izbivanja iz Francuske, godine 1285. imenovan je biskupom u gradu Mende. Papa Honorije IV. potvrdio je ovo imenovanje sljedeće godine, 4. veljače 1286., a Durand je službe u biskupskoj kuriji povjerio raznim službenicima. Zbog poslova koje je imao unutar papinske države, njegov dolazak u biskupiju Mende ostvario se tek nekoliko godina kasnije budući da je papa Honorije IV. zahtijevao nastavak njegove službe u sjevernoj Italiji (usp. BULMAN 2008: 72). Papa Bonifacije VIII. 1295. nudi mu i Ravensku biskupiju, no on ju odbija prihvatiti. Umire u Rimu 1. studenoga 1296., a o značaju koji je imao u Crkvi te važnosti njegova rada svjedoči epitaf s njegova groba u crkvi Santa Maria sopra Minerva u Rimu. ${ }^{13}$

\subsection{Liturgijsko izlaganje ${ }^{14} \mathrm{RDO}$}

Durandov opsežan liturgijski traktat RDO-a nalazimo u dvije redakcije, prvoj iz 1291./1292. i drugoj, konačnoj, iz 1294./1296. (usp. THIBODEAU 2010: XVII). RDO predstavlja vrhunac pisanja liturgijske ekspozitorske literature čije početke nalazimo u otačkome razdoblju. ${ }^{15}$ Nemjerljiv utjecaj na ovu književnu vrstu imao je rad Amalara iz Metza (775./780. - 852./853.) koji u liturgijska izlaganja, u vrijeme karolinške reforme, uvodi alegorijsku metodu tumačenja, posebice u djelu De officiis. ${ }^{16}$ Alegorijsko tumačenje Amalaro-

\footnotetext{
${ }^{13}$ Cjeloviti tekst epitafa v. FORCELLA 1869: 411.

${ }^{14}$ Uporabom nazivlja u ovome radu predlaže se da se za pojedina djela koja se u stranoj literaturi nazivaju liturgijskim ekspozicijama u hrvatskoj literaturi koristi naziv »liturgijsko izlaganje«. Jednako tako i književna vrsta unutar teološkoga pisanja trebala bi se nazivati jednako. Čitav skup takve literature, različita sadržaja od otačkoga vremena sve do 16. stoljeća, trebao bi se nazivati »liturgijska ekspozitorska literatura«. Ako je pojedini komentar svojim sadržajem obuhvatio samo pojedine sakramente, ili pojedinu stvarnost vezanu uz liturgiju Crkve, tada se taj komentar treba nazivati »izlaganje«, uz dodatak o čemu sadržajno govori, na primjer, »izlaganje o misi«. Kad se unutar pojedinih srednjovjekovnih zbornika pronađu pojedini elementi liturgijske ekspozitorske literature, trebalo bi ih označiti kao »liturgijske ekspozitorske elemente «.

${ }^{15}$ O liturgijskim izlaganjima u otačkome razdoblju v. VOGEL 1986: 10-11.

${ }^{16}$ O liturgijskim izlaganjima u vremenu od karolinške reforme do 13. stoljeća v. VOGEL 1986: $12-16$.
} 
ve tradicije donosi novo rješenje za tumačenje liturgije, odnosno »svaka gesta, procesija, liturgijska odjeća i arhitektonska struktura može biti razmatrana i interpretirana u alegorijskom smislu kao upućivanje na 'više' ili 'otajstvene' istine koje su utjelovljene u vršenju liturgijskog čina« (THIBODEAU 2010: XIX). Durand o svom razumijevanju alegorije unutar liturgijskog izlaganja govori u Prologu čitavom RDO-u (u nastavku teksta: RDO Pr). Naime, u RDO Pr 10 bilježi da za njega alegorija znači imati »drugi smisao «. ${ }^{17}$

U sastavljanju RDO-a Durand nije originalan autor, već se koristi postojećom liturgijskom ekspozitorskom literaturom kako bi sastavio djelo koje klericima treba objasniti dublji smisao liturgijskoga slavlja. ${ }^{18}$ Kao crkveni prav-

$1^{17}$ Allegory is present when what is said literally has another meaning spiritually; for example, when one word or deed brings to mind another. If what is represented is visible, then it is simply an allegory; if it is invisible and celestial, then it is called anagogy. Allegory also exist when an unrelated state of affairs is shown to exist trought the use of strange or alien expressions; when, for example, the presence of Christ or the sacraments of the Church are signified in mystical words or signs; in words: A branch shall come forth from the root of Jesse (Isa 11:1), which plainly means: the Virgin Mary shall be born of the stock of David, who was the son of Jesse. Mystical deeds can signify in the same fashion the freedom of the people of Israel from Egyptian slavery by the blood of (paschal) lamb, wich signifies the Church snatched away from the clutches od the Devil through the Passion of Christ. The word allegory comes from the Greek word, aleon, wich means 'strange' and gore, wich is 'sense'; that is, allegory means having 'another sense' « THIBODEAU 2010: 4. (»Alegorija je prisutna kada ono što je rečeno ima drugo, duhovno značenje. Na primjer, kada jedna riječ ili značenje vodi prema drugomu. Ako je ono što je predstavljeno vidljivo, tada je to jednostavno alegorija, ako je nevidljivo ili nebesko, tada se to zove anagogija. Alegorija također postoji kada nepovezane situacije pokazuju postojanje kroz uporabu stranih ili dalekih izraza. Na primjer, kada su Kristova prisutnost ili sakramenti Crkve označeni kroz otajstvene riječi ili znakove. Riječima: 'Isklijat će mladica iz panja Jišajeva' (Iz 11, 1), što jasnije znači: 'Djevica Marija rodit će nasljednika Davidova, koji je sin Jišajev'. Na isti način ovo otajstveno može označivati slobodu izraelskoga naroda od egipatskoga ropstva po krvi pashalnoga jaganjca, a što označava Crkvu otetu iz đavolskih kandži kroz Kristovu muku. Riječ alegorija dolazi od grčke riječi 'aleon', što znači 'stran', i 'gore', što je 'smisao'. Tako alegorija znači imati 'drugi smisao'.«-prijevod S. K.).

$18 »$ The word Rationale is appropriately used as the title of this book, becuse just as 'revelation and truth' were written on the pectoral od judgment that the High Priest bore on his vestments, so too the Rationale contains the reasons for the variations in the Divine Offices, and their inner meaning is described and made manifest. The prelates and priests of the Church should faithfully keep these truths in the chamber of their heart. In the pectoral of judgment, moreover, there was a stone by whose splendor the sons of Israel could know that God's favor was with then. In the same way, the devout reader, instructed in the mysteries of the divine offices by the spendor of this book, will be able to know that the God's favor will be with us, unless we incur his indignation through the commission of some sin. The pectoral was embroidered with four colors and golden thread, and now, as I stated before, the reason for the variety of ecclesiastical offices can be said to correspond to these four colors and are understood through the four senses; namely, the historical, allegorical, tropological, 
nik, Durand je u RDO uključio raznovrsne kanonskopravne izvore, što neki autori vide kao originalnost, odnosno Durand je originalan u načinu na koji upotrebljava tu vrstu dotad postojeće literature. Naslovi koje nose knjige (lat. libri), odnosno veće cjeline unutar RDO-a otkrivaju opći sadržaj raspravljenoga: $O$ crkvi, $O$ crkvenim službenicima i redovima, $O$ svećeničkoj odjeći, $O$ misi, O božanskoj službi, O posebnim crkvenim slavljima, O slavljima svetaca te $O$ određivanju datuma Uskrsa i kalendaru.

\subsection{RDO V - De officiis}

Tekst RDO V je posvećen božanskoj službi ili oficiju. Važno je istaknuti kako cjelovit RDO svoj konačni oblik dobiva u trenutku miješanja dviju liturgijskih tradicija službe časova, odnosno kada u katedralni oficij ulaze elementi monaškoga (THIBODEAU 2015: 19). Kako smo naveli, Durandov je cilj obrazložiti liturgijska slavlja, a tumačenja se odnose na obrede prisutne u čitavom zapadnome svijetu. Ipak, s pogledom RDO V, Durand pojašnjava tijek obreda oficija u Rimu. Durand ne donosi distinkciju s obzirom na tradiciju oficija, već - stvarajući referentno djelo za sveučilišnu upotrebu - nastoji što jasnije i jednostavnije prikazati raspored i smisao obreda (DURANDUS 1995: 10). Nakon RDO Pr, u prvom poglavlju RDO V Durand donosi uvid u cjelokupnost oficija, prikaz elemenata svih časova. Tumači značenje molitve Oče naš, znaka križa, himna, antifona, neuma, psalama, redaka prije čitanja, čitanja, otpjeva, euholoških obrazaca, blagoslova, dopunskih molitvenih obrazaca te pjevanja tijekom oficija, dok je ostatak knjige usmjeren pojedinim časovima oficija. Poradi uporabe četverostruke egzegetske metode (alegorija, tropologija, anagogija i povijesna metoda) tumačenje oficija obiluje vezama s poviješću spasenja i spasiteljskim djelom Isusa Krista, različitim moralnim uputama, naukom o Crkvi te upućivanjem na eshatološke stvarnosti. Drugim riječima, svaki od crkvenih obreda svoj temelj - istinu koja ga iznutra čini

and anagogical, with faith (gold) at the center of all colors. «THIBODEAU 2010: 6. (»Riječ 'rationale' prikladno je upotrijebljena kao naslov ove knjige, upravo kao što su na prsnom oklopu Velikoga svećenika stajale riječi 'otkrivenje' i 'istina'. Tako i 'Rationale' sadrži raz$\log$ za varijacije u božanskim službama te je njihovo unutarnje značenje opisano i očitovano. Crkveni prelati i svećenici vjerno trebaju čuvati ove istine u odajama svojih srdaca. Na pektoralu suda, štoviše, stajao je kamen po čijem su sjaju sinovi Izraelovi mogli spoznati da je s njima bila Božja milost. Na jednak način, pobožan čitatelj, poučen po sjaju ove knjige o otajstvima božanskih službi, znat će da je Božja milost s nama, osim ako nisu izazvali njegov bijes čineći neki grijeh. Pektoral je bio vezan četverobojnim i zlatnim nitima, a sada, kako sam prije naveo, razlog različitosti crkvenih službi korespondira tim četirima bojama te su shvaćene kroz četiri razine smisla, točnije povijesno, alegorijski, tropološki i anagoški, s vjerom (zlatom) u središtu svih boja.«-prijevod S. K.). 
smislenim u životu zajednice - nalazi u Mojsijevu Zakonu koji je dan Ocima. Zakon u sebi sadrži mistične i moralne elemente. Moralni oblikuju našu narav, karakter, dok mistične označuju ono što se nalazi iza doslovnoga smisla. Mistični elementi Zakona mogu biti sakramentalni, za koje postoji jasan razlog postojanja u Zakonu te su stoga nepromjenjivi, i ceremonijalni, za koje taj razlog ne postoji te su zato promjenjive naravi. Mnoge su se sakramentalne i ceremonijalne odredbe promijenile, ali smisao ostaje isti, odnosno - kako Durand navodi - »tako da ne može biti rečeno da je Zakon promijenjen kako je prešao nama« $(R D O \operatorname{Pr} 8)$.

\section{IZABRANI ELEMENTI I SIMBOLIKA PREDTRIDENTSKOG OFICIJA U DURANDOVU RDO V}

U nastavku rada prikazat ćemo Durandovo tumačenje uz antifone (De antiphonis) u RDO V,2[4], uz psalme (De psalmis) u RDO V,2[6] te uz noćnu službu (De nocturnis) u RDO V,3,1-37. Brojevi u uglatim zagradama, doneseni za drugo poglavlje RDO V, označavaju manje cjeline unutar toga dijela RDO-a. No, te zagrade donosimo samo kako bismo označili točno mjesto unutar kritičkog izdanja. Budući da i u samom kritičkom izdanju brojevi odlomaka teku redom kroz sve manje cjeline, unutar analize nakon broja knjige (npr. RDO V) i broja poglavlja unutar knjige (npr. RDO V,2), ne donosimo broj manje cjeline (npr. RDO V,2[4]), već odlomak koji navodimo ili parafraziramo (npr. RDO V,2,3).

\subsection{O antifonama (RDO V,2[4])}

Prema Durandu, antifone označavaju smisao kršćanskoga života: significat caritatis copulam seu mutuam dilectionem, sine qua opus non prodest et per quam incipit opus meritorium esse (RDO V,2,27). ${ }^{19} \mathrm{Zbog}$ toga se antifone i psalmi koji slijede pjevaju istim tonom. Tako djeluju izmiješani, bez posebne podjele i naznake početka psalma, a sve kako bi se zadržala simbolika i veza sa svakodnevicom u kojoj kršćanska djela moraju biti oblikovana ljubavlju (usp. RDO V,2,27), što ćemo posebno vidjeti kod tumačenja o psalmima.

Durand navodi tradiciju da se na početku psalma antifona otpjeva djelomično (tj. nesavršeno), a na kraju u cijelosti. Ovomu pripisuje simboliku nesavršenosti milosrđa u ovom životu koje će kroz dobra djela, što ih označavaju psalmi, biti usavršeno u domovini na nebesima. Ipak, navodi kako se

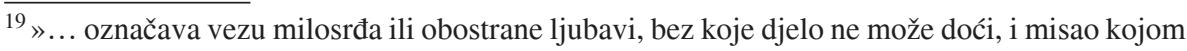
djelo zadobiva svoju vrijednost« (prijevod S. K.). 
na svetkovine antifone i na početku i na kraju pjevaju cjelovito, jer vršitelji službe Božje, ili vršitelji oficija time žele izraziti želju da tih dana budu što savršeniji pred Bogom.

Donoseći tumačenje o obrednosti pjevanja antifona, Durand navodi da antifonu zapjeva najprije jedna osoba, a završavaju svi u oba kora, čime označava da je po Kristu, pravomu čovjeku i Bogu, milosrđe započeto, a po Kristu je ono došlo i u svaki od udova zajednice. Kako navodi Durand: Deus enim prior dilexit nos, unde et nos communiter dilectioni eius correspondere debemus (RDO V,2,28). ${ }^{20} \mathrm{Na}$ ovome se mjestu još jednom potvrđuje Durandova, ranije tek kratko spomenuta, usmjerenost uključivanju eklezioloških tema u korpus RDO-a. Tako osoba koja započinje antifonu simbolizira propovjednike koji semper ad unitatem tendit, nos monet ut quod unusquisque singulariter operando acquirit, alteri per dilectionem porrigat, ut, si unus addiscit in scolis et alter seminat in campo, tempore fructus doctor seminanti doctrinam porrigat et sator doctori panem (RDO V,2,28). ${ }^{21}$ Osim toga, nakon otpjevana psalma antifonu izgovaraju oba kora, quia de dilectione commune gaudium surgit (RDO V,2,29), ${ }^{22}$ odnosno coniungit antiphona duos chorus, ut caritas per bonum opus coniungat duos fratres (RDO V,2,29). ${ }^{23}$ Ako bi svećenici, i oni koji mole oficij prema vlastitomu staležu, usvojili ova značenja, tada bi - prema Durandu - značenje antifona trebalo biti za svakog sudionika slavlja poput pjesme, kantilene, koja treba voditi obnovljenom razumijevanju crkvenosti (usp. RDO V,2,30-31).

Pri kraju izlaganja o antifonama, u RDO V,2,31 Durand navodi kako se prije psalama noćne službe u ferijama govori šest antifona. Broj šest dovodi u vezu sa šest tjelesnih djela milosrđa. Budući da danas govorimo o sedam tjelesnih djela milosrđa (gladna nahraniti, žedna napojiti, siromaha odjenuti, putnika primiti, bolesna i utamničena pohoditi, zarobljenike i izbjeglice pomagati, mrtve pokopati), Durand uzima broj šest vjerojatno na temelju 25. poglavlja Matejeva evanđelja: »Jer ogladnjeh i dadoste mi jesti; ožednjeh i napojiste me; stranac bijah i primiste me; gol i zaogrnuste me; oboljeh i pohodiste me; u tamnici bijah i dođoste k meni.« Mt 25,35-36 mjesto je na kojem nalazimo Isusov »popis« djela milosrđa, a na temelju kojega je Crkva kasnije

${ }_{20}$ Budući da je Bog nas prve ljubio, stoga kao zajednica težimo biti u jedinstvu njegove ljubavi« (prijevod S. K.).

$21 » \ldots$ uvijek teže prema jedinstvu, upozoravaju svakog pojedinog od nas da ono što smo stekli u vlastitom specifičnom poslu, ponudimo drugom kroz ljubav, tako da ako jedan poučava u školama, a drugi sije u polju, u vrijeme žetve učitelj će podijeliti svoje učenje sijaču, a ratar svoj kruh s učiteljem« (prijevod S. K.).

$22 » \ldots$ budući da iz ljubavi izrasta zajednička radost« (prijevod S. K.).

23 »Antifona ujedinjuje dva kora, kao što ljubav ujedinjuje dvojicu braće« (prijevod S. K.). 
promišljala o milosrđu u različitim kontekstima. Broj šest, povezan s djelima milosrđa, savršeni je broj, a ovim tumačenjem Durand smjera na potrebu savršenstva, posebno djelâ, što ga u svojim svakodnevicama trebaju odražavati vršitelji oficija. Dodatan naglasak na eklezijalnu dimenziju tumačenja obrednosti osnovnih elemenata oficija Durand donosi u tumačenju psaltira, koji - promatran zajedno sa antifonama - simbolizira savršen kršćanski život.

\subsection{O psalmima (RDO V,2[6])}

Psalmi, koji u tijeku oficija dolaze nakon antifona, pjevaju se istim tonom kao i antifone (simphoniam antiphone) (usp. RDO V,2,36). U nastavku izlaganja Durand donosi tumačenje koje je djelomično predstavio prilikom izlaganja o antifonama:... significat psalmus bonam et divinam operationem, unde David: 'In psalterio decachordo psalam tibi': in tali enim instrumento psallebat, innvens quod in psalterio spirituali, spiritu vivificati per fidem, debemus psallere Deo, decem legis mandata implendo (RDO V,2,36). ${ }^{24}$

Prema Durandu, papa Damaz je ustanovio za čitavu Crkvu pjevanje psalama u dva kora kako bi se nadišla zbrka dotadašnje prakse. Pritom se koristi igrom riječi (chorea - chori) koja se u prijevodu teksta gubi: Priscis namque temporibus confuse et quasi in chorea dicebantur, ideoque sancti patres ordinaverunt ut alternatim dicerentur, id est una pars chori unum versum, altera alium didiceret... (RDO V,2,36) ${ }^{25}$ Sveti Ignacije Antiohijski prvi je ustanovio ovakav raspored slavlja za mjesnu Crkvu u Antiohiji, nakon što je, kako navodi Durand, imao viziju u kojoj su anđeli pjevali psalme antifonalno, to jest naizmjenično.

Antifonalno pjevanje psalama u koru u Durandovu tumačenju ima ekleziološko značenje, posebice ako u obzir uzmemo tumačenje koje donosi u RDO I,1,18, pod naslovom De ecclesia et eius partibus. U navedenom broju donosi tumačenja vezana uz dio crkve koji se naziva kor, mjesto gdje se kler sakupljao na molitvu: Sane chorus clericorum est consensio cantantium vel multitudo in sacris collecta. Dictus est autem chorus a chorea vel a corona: olim enim in modum corone circum aras stabant et ita psalmos concorditer

\footnotetext{
${ }^{24}$ »Psalmi označavaju dobra i božanska djela, prema Davidu: 'Pjevat ću ti, Bože, pjesmu novu, na harfi od deset žica svirat ću' (Ps 143, 9). Instrument uz koji je pjevao psalme podsjeća nas da Bogu psalme trebamo pjevati na duhovnom psaltiru, duhom vraćenim u život vjerom i izvršavanjem deset zapovijedi Zakona« (prijevod S. K.).

25 ॥ prošlim vremenima psalmi su izgovarani na konfuzan način, kao u krugu (na konfuzan način govora u teatru). Stoga su sveti oci odredili da će biti izgovarani naizmjenično - jedan dio će pjevati jedan vers, a drugi dio drugi vers« (prijevod S. K.).
} 
concinebant... (RDO I,1,18). ${ }^{26}$ Između ostaloga, u navedenom broju Durand donosi još jednu mogućnost tumačenja, izvedenu iz pojašnjenja uz nastanak pojma kor: Alii chorum dixerunt a concordia que in caritate consistit quia qui caritatem non habet convenienter cantare non potest (RDO I,1,18). ${ }^{27}$ Bitan preduvjet molitve u ovom slučaju je jedinstvo unutar zajednice. To jedinstvo simbolizirano je podjednako oblikovanjem liturgijskoga prostora kao i formom slavlja, to jest unisonim pjevanjem. Tako se molitva ovdje prikazuje kao trenutak života Crkve u kojemu se kršćani, molitelji, ali i mogući promatrači, mogu osvjedočiti u jednu od njezinih bitnih značajki, a to je njezino jedinstvo iz kojega se lako može iščitati ostale, odnosno apostolicitet, katolicitet i svetost.

Kada se oficij moli u koru, odnosno zajednički, psalmi se izgovaraju stojeći, u uspravnomu stavu. Uspravan stav za vrijeme molitve oficija treba podsjetiti vršitelje oficija da će se spasiti samo ako budu vjerno vršili dobra djela u svakodnevnom životu, ili, kako donosi Durand: ... stantes in bonis operibus vincimus (RDO V,2,36). ${ }^{28}$ Nadalje, ustati kako bi se stajalo označava usmjerenost uma na ono što je važno, usmjerenost duha na nebeske stvarnosti (usp. RDO V,2,36). Uspravnošću tijela vršitelj oficija pokazuje da je spreman krotiti tijelo (domandum carnem) i vršiti dobra djela (exercitium operis) (usp. RDO V,2,36). Kada se slušaju lekcije, poput dužih lekcija noćne službe ili kraćih u ostalim dijelovima oficija, vršitelji oficija sjede, što označava da se riječ mudrosti treba slušati i prihvaćati u tišini i miru, kako bi se kasnije iz dobro shvaćena teksta moglo ispravno djelovati (usp. RDO V,2,36).

U RDO V,2,37 Durand iznova donosi tumačenje vezano uz broj šest, ovaj put uz šest psalama koji se kroz dan govore unutar časova oficija. Šest je takvih psalama, a njihov broj označava, kao i kod antifona, broj djela milosrđa. Oni koji mole, kao radnici u vinogradu Gospodnjemu (lat. in vinea Domini laborantes), trebaju težiti usvajanju i vršenju djela milosrđa u svakodnevici. Vršitelji oficija se, takvim životnim stavom, očišćenošću uma i srca te iskreno pobožni, oslobađaju ropstva zla, postaju slobodni ljudi, oslobađaju se iz zamke Đavla te će, kao vjerni vršitelji zapovijedi na kraju dana, odnosno života, dobiti zasluženu dnevnicu (usp. RDO V,2,37). Na ovome mjestu Durand svoje tumačenje usmjerava prema eshatološkim stvarnostima, odnosno upo-

26 »Klerički kor harmonično je mjesto okupljanja pjevača, ili okupljalište mnoštva na slavlje svetih otajstava. Riječ kor dolazi od chorea ili corona. Tome je tako budući da su u prošlosti klerici stajali oko oltara u krugu te su psalme pjevali unisono...« (prijevod S. K.).

27 »Drugi kažu da kor dolazi od riječi zajedništvo koje dolazi s ljubavlju prema bližnjemu, budući da onaj kojemu nedostaje te ljubavi ne može pjevati unisono s ostalima« (prijevod S. K.).

28 »... stojeći u dobrim djelima, pobijedit ćemo« (prijevod S. K.). 
zorava da će samo oni koji su vjerni vršitelji podjednako i molitve i zauzeta kršćanskoga djelovanja jednom biti spašeni. Kako bi dodatno pojasnio ono što želi reći, nešto kasnije Durand, citirajući svetoga Jeronima, donosi: quod melior est quinque psalmorum cum cordis purate ac serenitate spiritualique ylaritate decantatio quam totius psalterii cum anxietate cordis atque tristitia modulatio (RDO V,2,38). ${ }^{29}$

RDO V,2,38 Durand posvećuje analizi sadržaja pojedinih psalama kako bi pokazao zašto se isti psalmi govore u više različitih slavlja tijekom godine. Zapravo navodi da se isti psalmi govore zbog poveznice teksta s pojedinim slavljem. To je slučaj s Ps 44 koji se govori na Božić, unutar slavlja Blažene Djevice Marije i na slavlja apostola, te s Ps 2 koji se također govori na Božić te na Veliki petak.

Ostatak tumačenja o psalmima Durand posvećuje gradualnim psalmima (psalmi graduales). Ti su psalmi bili dio židovske hodočasničke obredne prakse, a pjevali su se prilikom ulaska u jeruzalemski, Salomonov hram, do kojega se uzlazilo preko petnaest stuba (gradus).

Prema Durandu quindenarius numerus constat ex numero septenario et octonario: septenarius refertur ad vetus testamentum quia antiqui septimum diem, septimum mensem et septimum annum celebrabant; octonarius ad novum testamentum refertur propter resurrectionem dominicam que octavo diefacta est (RDO V,2,39). ${ }^{30}$ Gradualni psalmi tako označavaju prijelaz iz Staroga u Novi zavjet, molitvu na prijelazu iz staroga u novo vrijeme, koje dolazi s Kristom, a i nadu u konačni dolazak osmoga dana koji je u kršćanskoj literaturi označavao vječnost, osmi Otkupiteljev dan, odnosno vječni sud i konačno opredjeljenje duše za ili protiv Boga. ${ }^{31}$ Prvih pet gradualnih psalama označava vrijeme ovoga života u kojemu čovjek čini mnoštvo grijeha putem pet osjetila. Nakon tih prvih pet psalama ne govori se Gloria Patri, jer djelo grijeha ne možemo pripisati Bogu, nego Requiem eterna - kako navodi Durand. Razlog je tome što se u redcima prvih pet gradualnih psalama moli Gospodina da

\footnotetext{
${ }^{29} \gg$ Bolje je pjevati pet psalama čistim srcem, duhovnom vedrinom i radošću, nego pjevati čitav psaltir sa zabrinutošću i tužna srca« (prijevod S. K.).

$30 » .$. broj petnaest dolazi od zbroja brojeva sedam i osam. Sedam se odnosi na Stari zavjet, budući da su stari običavali slaviti sedmi dan, sedmi mjesec i sedmu godinu. Osam se odnosi na Novi zavjet zbog Gospodinova uskrsnuća koje se dogodilo osmoga dana« (prijevod S. K.).

${ }^{31}$ Himan Auctor perénnis glórice donosi svjedočanstvo o važnosti simbolike osmoga dana u kršćanstvu: Septem diérum cúrsibus / nunc tempus omne dúcitur; / octávus ille últimus / dies erit iudícii, // In quo, Redémptor, qucesumus, / ne nos in ira árguas, / sed a sinístra líbera, / ad déxteram nos cólloca. U hrvatskome prijevodu: »Evo, sve nam vrijeme teče / S nizom ovih sedam dana: / Posljednji će osmi biti / Sudnji dan Otkupiteljev. // Tada, Spase, molimo te, / Lik svoj blagi nam pokaži, / Lijeve strane oslobodi, / Zdesna sebi sve nas smjesti.«
} 
umrlima, koji su činili grijehe putem pet osjetila, dadne oproštenje grijeha i vječni pokoj u svomu milosrđu. Durand ovdje ne govori o službi za pokojne, već za pet prvih gradualnih psalama dodaje simboličko značenje molitve za pokojne. Kako sam zapisuje, u pameti molitelja navedenih pet psalama trebala bi biti molitva Oramus, Domine, ne pro peccatis illis, que committuntur corporis sensibus eis vita negetur eterna; sed, per Dei misericordiam, requies concedatur eterna. ${ }^{32} \mathrm{U}$ ostalim gradualnim psalmima Boga se moli za žive, za laike i kler (lat. nostris proximis et congregationibus et prelatis). Osim toga, $\mathrm{u}$ broju deset Durand pronalazi simboliku dviju ploča Mojsijeva Zakona, deset Božjih zapovijedi, odnosno deset je zbroj brojeva tri i sedam; na prvoj su ploči sadržane tri zapovjedi koje se odnose na Boga, a na drugoj sedam koje se odnose na međuljudske odnose.

Kao što smo već spomenuli, uz tumačenja gradualnih psalama Durand veže i ekleziološke teme. U RDO 1,2,13, mjestu na kojemu donosi tumačenja uz oltar, odnosno njegovo oblikovanje simbolično dovodi u vezu s duhovnim stvarnostima, navodi da gradus quibus ad altare ascenditur spiritualiter demonstrant apostolos et martyres Christi quos, quia pro eius amore sanguinem suum fuderunt (RDO I,2,13). ${ }^{33}$ Molitva gradualnih psalama podsjeća vršitelje oficija na temelj na kojemu su sagrađeni, a to je početak kršćanske zajednice - Crkve i početak svjedočenja vjere u Krista koje je bilo označeno krvavim progonima koji tu istu zajednicu nisu uspjeli srušiti. Molitva tako molitelju pokazuje da nije sam, ni u sadašnjosti, jer mnogi su uz njega u istom krugu, možda samo u različitosti intenziteta svakodnevne brige, ni s pogledom na prošlost, jer mnogi su mu prethodili, posebno apostoli koji su jamac istinitosti nauka, temelj jedinstva, početak svetosti i otvorenosti narodima, po poslanju koje su dobili od Krista. U istom broju, uz navedeno, donosi još jednu mogućnost tumačenja broja petnaest: Exprimunt quoque quindecim virtutes que significatur per quindecim gradus quibus ascendebatur in templum Salomonis, et a Propheta in quindecim psalmis continue demonstrantur quos beatus vir ascensiones in corde suo disposuit (RDO I,2,13). ${ }^{34}$ Durand ne donosi popis tih petnaest vrlina, možda taj broj uzima gledajući neko od »stabla vrlina« (usp. MARCHESE 2013: 363), ali to nam nije toliko važno koliko činjenica

$32 » .$. Molimo, Gospodine, da ne izgube vječni život poradi grijeha koje su učinili kroz tjelesna osjetila, nego da uz pomoć Božjega milosrđa zavrijede vječni pokoj.« (prijevod S. K.).

$33 » .$. stube po kojima se uspinje do oltara duhovno predstavljaju Kristove apostole i mučenike koji su, poradi ljubavi prema njemu, prolili svoju krv...«(prijevod S. K.).

${ }^{34}$ »Stube također predstavljaju petnaest vrlina koje, označene s petnaest stuba kojima se uzlazilo u Salomonov hram te s prorocima, u sebi prezentiraju uzastopni psalmi, čime je označeno da blaženi čovjek mora takve stube urediti u svome srcu« (prijevod S. K.). 
da se ovim tumačenjem od molitelja traži usklađenost nutrine s vanjštinom, posebno u navještaju vjere, a još više u trenutcima kada vjernik stoji pred Bogom, u trenutcima kada komunicira s njim. Molitva je trenutak u kojemu vjernik komunicira s Bogom, a, ako želi da Bog svrati pogled na njega, mora se pokazati kao onaj koji malo-pomalo nastoji rasti u krjepostima, kao što se stubištem uspinje do vrhunca, do cilja kojemu se stubama dolazi. Usvajajući krjeposti, jednu po jednu, vjernik se malo-pomalo uspinje do neba, gdje će gledati Boga kakav jest, a ne više komunicirati s njime putem molitve koja je tek predokus onoga što se očekuje s one strane stvarnosti. Taj prijelaz se može opisati kao hod iz tame noći, iz ograničenosti spoznaje s ove strane vječnosti, prema svjetlu dana, punini svega onoga što ljudskom biću nedostaje za života, a zadobiva se u Bogu. Ipak, koliko god čovjek bio ograničen u spoznavanju za vrijeme noći, i tada je obvezan komunicirati s Bogom. Stoga, uz ostalo, Durand jedan dio svog tumačenja u RDO V posvećuje simbolici obrednosti noćne službe.

\subsection{O noćnoj službi (RDO V,3,1-37)}

Na početku tumačenja noćne službe Durand navodi da Crkva oficij započinje molitvom vespera. Ipak, zbog simbolike koju sadrži noćna služba u kontekstu tumačenja Levitskoga zakonika (Lev 23,32) primjereno je oficij započeti slavljem ovoga molitvenog dijela dana (usp. RDO V,3,1). Drugim riječima, Durand iznosi činjenicu da molitva oficija završava molitvom vespera pojedinoga dana, no, kako bi dodatno naglasio simboliku ove molitve, uzima primjerenim tumačenje započeti slavljem noćne službe, prema navedenomu starozavjetnome tekstu u kojemu se govori o slavljenju Boga od noći do noći: Sabbatum requietionis est vobis, et affligentis animas veterios; die nono mensis a vespero usque ad vesperum servabitis sabbatum vestrum. Noćni oficij se pjeva noću zbog pet razloga: 1. noću su ubijeni egipatski prvorođenci, a izraelski je prvorođenac Mojsije spašen; 2. tada je rođen Sin Božji, za čiji dar u toj službi zahvaljujemo; 3 . Krist je tada uhvaćen, ali je u noći i uskrsnuo, u noći će iznova doći; 4 . u to će vrijeme i naši grijesi, tame, biti prosvjetljeni; 5 . moli se u to doba kako bi se ukrotila zamamnost tijela (usp. RDO V,3,2).

U noćnoj službi govore se tri tzv. nokturna ${ }^{35}$ na spomen prve Crkve u kojoj su svi ljudi, prema staležima, ustajali tri puta tijekom noći kako bi slavili Boga. Kako Durand navodi, to noćno ustajanje službenika i naroda označavalo je tri razdoblja povijesti spasenja: prije nego je Bog Mojsiju dao Zakon,

\footnotetext{
${ }^{35}$ U kontekstu hrvatskoga nazivlja, za oficij koji se obavlja noću koristimo naziv noćna služba, dok za raspored psalama u toj službi koristimo naziv nokturn.
} 
zatim vrijeme pod Zakonom te vrijeme milosti nakon Kristova dolaska. U RDO V,3,3 donosi raspored slavlja noćne službe u prvoj kršćanskoj zajednici: ... ministri Ecclesie ter de nocte interpolatim surgebant... Surgebat enim prima circa primun sopnum quando vulgus solet ire dormitum, secundo circa mediam noctem, tertio paululum ante diem sic ordinantes officium ut nocturne finite et lectiones cum suis responsoriis perlecte essent prius quam lucesceret. Apparente vero aurora, pulsatis campanis, cantabant Te Deum laudamus et matutinas laudes. ${ }^{36} \mathrm{No}$, nije cijela zajednica ustajala na slavlje čitava noćnog oficija. U nastavku RDO V,3,3 navodi kako se na slavlje prvoga nokturna, koji je započinjao invitatorijem, skupljao samo kler sa svojim biskupom (lat. pontifex solum et ministri Ecclesiae surgebant), a služba se nazivala bdijenjem (lat. vigilia) quia habuit initium a pastoribus vigilas noctis super greges suos (RDO V,3,3). ${ }^{37}$ Ipak, za posebne svetkovine sakupljao se sav narod. Na drugi nokturn ustajao je kler i oni koji su oženjeni, podjednako i muškarci i žene, a započinjao je invitatorijem ad significandum angelos invitantes pastores ad videndum regem natum (RDO V,3,3) ${ }^{38} \mathrm{Na}$ treći nokturn ustajala je čitava zajednica. Prema Durandu, lijenost je bila uzor, što je kasnije statutum est ut omnes media nocte surgere ... et totum noctis officium continue cantaretur, et plures adhuc illa hora surgunt (RDO V,3,3). ${ }^{39}$ Kako je vrijeme odmicalo i taj oblik službe bio je zanemarivan te je, na kraju, određeno da se treba ustati barem na treći nokturn. U bilješci uz novo izdanje engleskoga prijevoda RDO V stoji kako Durand nigdje ne navodi koji su mu izvori za ovakav raspored i način slavlja noćnog oficija prve kršćanske zajednice (usp. DURAND 2015: 122). Ipak, barem u teološkome smislu, odnosno za potrebe alegorijskog tumačenja, možemo uzeti da je ovo svojevrsna opomena Durandovim čitateljima kako bi bili pozorni i revni u obavljanju oficija kako im je dan. ${ }^{40}$

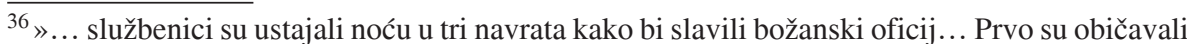
ustajati za prvoga sna, kad su mase imale običaj ići spavati; drugo, usred noći; treće, nešto prije zore. Tako uređujući oficij, nokturni su bili završeni, a čitanja s responzorijima pročitana prije izlaska sunca. Kad je dan započeo, zvona su zvonila, a oni su pjevali Tebe Boga slavimo« (prijevod S. K.).

$37 » \ldots$ jer su noću pastiri bdjeli nad svojim stadom...«(prijevod S. K.).

38 ».. da bi se označilo anđele koji su pastire pozvali vidjeti novorođenoga Kralja« (prijevod S. K.).

$39 » \ldots$ određeno da svi trebaju ustati u ponoć ... i da se čitav noćni oficij pjeva kontinuirano te da, zbog mnogih, toga sata trebaju ustati« (prijevod S. K.).

${ }^{40} \mathrm{U}$ izdanju »totuma« cjelovita jednosvezačnoga oficija, nakon reforme pape Ivana XXIII. 1961. godine, stoji suvremenicima zanimljiv dodatak o broju dana, odnosno godina oprosta koje mogu zadobiti oni koji vjerno vrše službu oficija, sami ili u koru. Ta činjenica možda je trebala potaknuti nemarne na njegovo moljenje. Sve nam ovo pokazuje, podjednako srednjovjekovna moralna pouka na temelju povijesno-alegorijskoga prikaza razvoja noćne 
U nastavku RDO V Durand piše da noćna služba ima četiri elementa: tri nokturna i jutarnju službu, kojima se označava borba protiv četiri neprijatelja Crkve: opakih duhova odozgor, zlonamjernih ljudi odozdo, požude tijela iznutra i zavodljivosti tijela izvana. Durand te neprijatelje označava kao superiores, inferiores, interiores i exteriores (usp. RDO V,3,4). Borba protiv tih neprijatelja izvršava se tijekom svakog pojedinoga nokturna koji započinje u trenutcima kada su ti neprijatelji na djelu: 1 . in conticinium - usred noći, 2. in gallicinium - za pjevanja pijetlova, 3. in intempestum - na kraju noći i 4. in antelucinium - $\mathrm{u}$ zoru prije dana.

\subsection{Nazivlje i simbolika rasporeda slavlja noćne službe prema RDO V,3}

Durand tek kratko donosi zapis uz nazivlje ovoga časa oficija. Naznačuje da nocturna-nocturne ponitur pro hora (RDO V,3,7), nocturni-nocturnorum pro officio ${ }^{41}$ (RDO V,3,7). Tako stoji da »nocturne u množini označavaju vrijeme u kojemu se psalmi pjevaju « (RDO V,3,7), a »nocturni-nocturne označavaju devet psalama i devet čitanja s responzorijima« (RDO V,3,7).

U RDO V,3,9 nalazimo raspored noćnog oficija: 1. Otvori, Gospodine, usne moje (lat. Domine, labia mea aperies), 2. Bože, u pomoć mi priteci (lat. Domine, in audiutorium meum intende), 3. Slava Ocu (Gloria Patri), 4. invitatorij s psalmom invitatorija, 5. himan, 6. psalmi s antifonama, 7. vers, 8 . lekcije s responzorijima, 9. Oče naš (lat. Pater noster), 10. oracija. Za svaki od navedenih dijelova koji su zajednički u svim tradicijama obavljanja oficija Durand donosi dublje značenje koje se krije ispod obrednosti. Redak Domine, labia mea aperies prenosi onoga koji vrši noćnu službu u »novo vrijeme «. Kako u nastavku tumači, molitelj traži da mu se otvore usta za molitvu, budući da se u kompletoriju predao Bogu, a njegov duh i tijelo (tj. usta i srce) zatvoreni su unutar utvrde koju osigurava Kristov križ. Ovaj se redak izgovara u jednini (Domine, labia mea aperies) jednako u pojedinčevoj molitvi kao i za vrijeme molitve u koru. Tako pjevači u koru odgovaraju na početni redak također u jednini (tj. lat. Et os meum annuntiabit laudem tuam). Time Durand iznova uvodi ekleziološke elemente u tumačenje: mnogi molitelji u koru invitatorijem postaju jedno, sjedinjena zajednica, Crkva koja u jedinstvu slavi Boga. Budući da postoje zle sile koje to jedinstvo nastoje razrušiti, a čovjek

službe kao i indulgencije dane moliteljima oficija, koliko se s vremenom praksa molitve prve crkvene zajednice razvodnila te na koje su sve moguće načine rimski prvosvećenici nastojali kler potaknuti na vršenje ove službe.

${ }^{41}$ Durand se koristi igrom riječi na latinskome jeziku. 
slab sam se ne može izboriti za sebe, molitelji odmah dodaju redak Deus, in audiutorium meum intende (usp. RDO V,3,9). Kroz ova dva uvodna retka, kojima započinje molitva noćne službe - a označavaju gratia per quam os aperitur et dyabolo per auxilium Dei repulso (RDO V,3,10) ${ }^{42}$ - omogućeno je za molitelje da u tom trenutku izvan molitve oficija ne postoji druga stvarnost. Durand upućuje vršitelje oficija da se toj službi treba posvetiti u potpunosti, a budući da razumije slabost ljudskoga, već u Prologu RDO V naznačuje kako ovaj redak na početku oficija treba podsjećati na činjenicu da vjernik bez Boga ne može učiniti ništa (usp. RDO V,2,7). Sigurnost da zlo neće napasti molitelja osigurava se znamenovanjem znakom križa. Kad je znak križa načinjen, molitelj je na neki način, Božjom milošću, zatvoren u sigurnost utvrde koja mu nudi prikladno mjesto i vrijeme za molitvu oslobođenu duhovnog uznemirivanja. Ovi redci evociraju ekleziološko tematiziranje Crkve kao societatis perfecti, kao i potvrde izrijeka extra Ecclesiam nulla salus na IV. lateranskom koncilu riječima »una vero est fidelium universlais Ecclesia, extra quam nullus omnino salvatur « (DENZINGER - SCHÖNMETZER 1965: 260). Vjernik je siguran unutar zidina savršenoga društva i savršene Crkve, te ga prostor izvan zidina ne bi trebao zanimati. Izvan zidina može se naći samo kao misionar, ili pak od Boga i Crkve ostavljen na milost i nemilost bezbožnoga svijeta.

Molitva Gloria Patri dodaje se odmah nakon uvodnih redaka koje smo prikazali, budući da, nakon što su molitelju usta otvorena za molitvu te nakon što je Boga zazvao za pomoć u borbi protiv đavla, jedino što preostaje jest dati Bogu slavu (usp. RDO V,3,10). U RDO V,2,21 Durand napominje kako Gloria Patri dicitur viginti quatuor vicibus in nocturnis festivitatum, ... quod fit in honorem duodesim apostolorum qui sunt duodecim hore diei, id est Christi, a vero sole illuminante, et sunt duodecim hore noctem, id est Ecclesiam, illuminantes, qui Dominum glorie in nocte huius seculi predicaverunt (RDO V,2,21). ${ }^{43}$ Iznova je na ovome mjestu dodano ekleziološko razumijevanje jednog elementa unutar oficija. Naime, kao što je već istaknuto da molitelj ovdje dobiva na simboličnoj razini sigurnost da nije sam u povijesti Crkve, tako i ovdje Durand donosi tumačenje koje moliteljima pokazuje na koji način sudjeluju u posvećivanju Crkve - vršeći vjerno molitvu kojom su svoje osobe i okolinu posvećivali temeljima zajednice, a to je ponajprije Krist, koji je vjerom prosvijetlio svakog apostola, te sami apostoli koji u jedinstvo

$\overline{42}{ } \ldots$ milost kroz koju su usta otvorena i Božju pomoć kojom je odbijena đavlova napast...« (prijevod S. K.).

$43 » .$. govori se dvadeset i četiri puta u noćnom oficiju na svetkovine,... što se čini na čast dvanaest apostola, koji su dvanaest sati jednoga dana, koji označava Krista što ih jedini prosvjetljuje. A oni (apostoli) su oni koji prosvjetljuju dvanaest sati noći, koja označava Crkvu što propovijeda Gospodina Slave u vremenu tame ovoga svijeta« (prijevod S. K.). 
vjere i kršćanskoga života uvode mnoge ljude. Toj službi priključen je i svaki vršitelj oficija, jer sudjeluje u gradnji velikog jedinstva unutar Crkve, koja je jedna, sveta, katolička i apostolska, ujedinjena vjerom koju su apostoli primili od Krista, čime je ona ujedno i apostolska i sveopća (katolička), a posvećena je ponajprije milošću Isusa Krista koji sve prosvjetljuje, jednako kao i po zauzetoj kršćanskoj molitvi (u ovom slučaju molitvom službene molitve Crkve, odnosno oficija), tako i po djelovanju.

Tako su kršćani pozvani ne samo djelovati - jer bi se tada zajednica pretvorila u ništa više od socijalne ustanove (koje u tom smislu nisu bile poznate u srednjovjekovlju, ali snižavanje uloge Crkve svakako je bilo poznato od najranijih vremena) - već su pozvani svoj život hraniti neprestanom molitvom. U Prologu RDO V Durand, u kontekstu govora o generalnom rasporedu slavlja oficija i posebno Gloria Patri, pojašnjava kako se u Crkvi izvršava Isusov zahtjev neprestane molitve. Naime, za dana Crkva moli četiri časa oficija, makar je dan podijeljen na dvanaest sati. Durand je svjestan ljudske slabosti te pojašnjava da je taj ljudski nedostatak nadoknađen trenutcima molitve, kako bi čovjek imao dovoljno vremena i za rad. Svaki od tih časova sadrži po tri psalma pa, kada se sve zbroji, oficij u tim časovima ima ukupno dvanaest psalama - po jedan za svaki sat u jednomu danu. Osim toga, nakon svakog od tih psalama dodaje se molitva Gloria Patri, koja moliteljima treba evocirati Božju pomoć koja je za njih prisutna u svim trenutcima između molitvenih časova (usp. RDO V,1,5).

Radost zbog jedinstva u vjeri Crkve trebala bi potaknuti pojedinog molitelja da mnoge ljude pozove i dovede pravoj vjeri kao misionar. Simbolika pozivanja vjeri, odnosno misionarskoga djelovanja koje je usmjereno tome da mnogi slave jednoga Boga unutar jedine istinite zajednice, Crkve, sadržano je unutar sljedećeg elementa oficija, a to je invitatorij ili pozivnik (usp. RDO V,3,10). Navedene činjenice Durand ističe kada zapisuje da se invitatorij govori glasno (alta voce) quia Mater Ecclesia per illud invitat omnes ad confitendum Domino iuxta illud: 'Venite filii audite me', quod notat secundus versus: 'Preoccupemus' etc. (RDO V,3,10). ${ }^{44}$

Nakon invitatorija slijedi psalam invitatorija. Sam invitatorij, koji se govori potiho, i psalam invitatorija, koji se govori glasno, trebali bi moliteljima evocirati povijest prve Crkve, odnosno trenutak kad je nakon progona izišla u javnost (usp. RDO V,3,11). Bog je u Crkvi najprije slavljen u tajnosti, posebno ako se u obzir uzmu progoni koji su nerijetko desetkovali članstvo,

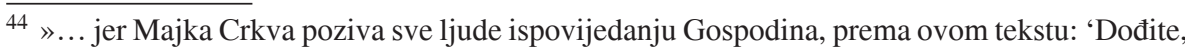
djeco' (Ps 33, 12), što je naznačeno u drugomu retku: 'Pred lice mu stupimo s hvalama' (Ps 94, 2)«(prijevod S. K.). 
no nakon što su progoni prošli, Crkva Boga manifeste propter alios ut ardor accendat proximos ${ }^{45}$ (RDO V,3,11), odnosno invitatorij rursum voce demissa inchoatur ad notandum quod in primitiva Ecclesia populus clam ad fidem et ad Christum colendum invitabitur, sed postea vox exaltatur ut ostendatur quod hodie libere invitatur, predicatur et adoratur ${ }^{46}$ (RDO V,3,11).

Himan, koji se - prema Durandu - u noćnoj službi pjeva odmah iza invitatorija i psalma invitatorija, također sadrži tumačenje koje se može vezati uz ekleziološku tematiku. Naime, himan je pohvala Bogu (lat. laus Dei) koju svi molitelji, odnosno oba kora, pjevaju zajedno. Time se ističe radost svih ljudi okupljenih unutar Crkve, to jest pjeva se in signum quod sicut legitur in Actibus Apostolorum gentes gauise sunt quia ad fidem vocate sunt ${ }^{47}$ (RDO $\mathrm{V}, 3,13)$.

Slijede antifone s psalmima, a u tumačenju Durand još jednom ističe ono što je već zapisao tumačeći posebno simboliku antifona i psalama. Drugim riječima, Boga se ne slavi samo ustima, već i dobrim djelima, koja simboliziraju psalmi, a jednako tako i ljubavlju bez koje nijedno dobro djelo ne može uspjeti (usp. RDO V,3,13).

Vers koji slijedi nakon antifona i psalama Durand u RDO V,3 tek spominje te čitatelje upućuje na mjesto gdje je u uvodnome dijelu dao njegovo tumačenje (usp. RDO V,3,13). O versu tumačenje donosi u RDO V,2,40-42. Unutar različitih časova oficija vers poprima različita značenja. Na ovome mjestu prikazat ćemo tumačenje koje donosi za vers u noćnoj službi. Unutar noćnog oficija vers significat quia ab officio psalmorum sive a labore tunc nos vertimus ad officia lectionum, sive ad quietem (RDO V,2,40). ${ }^{48}$ Drugim riječima, radnici ne mogu neprestano raditi, ne mogu neprestano moliti i činiti dobra djela, već se ponekad valja povući u tišinu boravka s Bogom koji poučava. Analizirajući Durandov tekst, može se reći da je vers trenutak u kojemu radnici u vinogradu Gospodnjemu odlažu svoj alat, antifone i psalmodiju, odnosno ljubav i dobra djela, kako bi aktivno odmarali i bili pogodno tlo u koje Gospodin sije sjeme Riječi koju su radnici pozvani navješćivati svojim radom.

\footnotetext{
$\overline{45} \gg$... za druge slavi otvoreno, tako da vatra može ogrijati one koji su blizu« (prijevod S. K.).

$46 » .$. počinje tihim glasom kako bi se označilo da su u prvoj Crkvi ljudi potajno pozivani njegovati vjeru u Krista i bogoslužje. No, nakon toga glas se podiže kako bi se označilo da su ljudi danas pozvani slobodno propovijedati i slaviti Boga« (prijevod S. K.).

${ }^{47} \gg . .$. kako bi se označilo ono što čitamo u Djelima Apostolskim, da su pogani bili sretni što su pozvani vjeri (usp. Dj 13, 48)« (prijevod S. K.).

48 »... označava da se tada okrećemo od oficija ili djela psaliranja prema službi čitanja, odnosno prema odmoru...« (prijevod S. K.).
} 
Unutar čitanja ili lekcija molitelji upijaju mudrost Riječi, nakon kojih slijedi molitva Oče naš. Ta molitva vršitelje oficija podsjeća na činjenicu da mudrost ili pouku traže jedino od Boga koji ih neće odbiti prema Jak 1,5. Uz to, ono što su čuli u čitanjima bit će uz Božju pomoć izvršeno, za što se moli molitvom Oče naš, a jednako tako ono što se postiglo neće biti razrušeno, jer se tom molitvom Boga moli za zaštitu te je ta molitva slika sigurne utvrde protiv đavlova neprijateljskoga djelovanja (usp. RDO V,3,14).

Molitva, ili oracija koja slijedi nakon molitve Oče naš, a dolazi prije čitanja lekcija, zaziv je svetih koji molitelju, svojim zagovorom pred Bogom, trebaju pomoći u ostvarivanju onoga što će se slušati. Ovdje je u molitveno zajedništvo uključena nebeska Crkva, odnosno Crkva proslavljenih u nebu, te iznova možemo govoriti o ekleziološkim implikacijama Durandova tumačenja. Ono za što se sveci mole jest mogućnost ostvarivanja sadržaja molitve. Čovjek je toliko slab da svojom snagom ne može jamčiti da će ono što moli biti i izvršeno. Tako se moli pomoć neba, Boga, da bi se moliteljeva nutrina dobro pripremila za slušanje lekcija, koje ne treba samo čuti već i poslušano izvršiti u svakodnevici. Na ovome mjestu evocira ulomak Lk 8, 5-7, pozivajući molitelje da u slušanju budu dobre njive na kojima će se sjeme dobro razvijati, ukorijeniti i u svoje vrijeme dati plod (usp. RDO V,3,15).

Nakon svega rečenoga slijede nokturni u užemu smislu riječi. Svetkovine imaju tri nokturna, dok ferije ${ }^{49}$ imaju samo jedan. Kada govorimo o tri nokturna, oni predstavljaju vrijeme prije Mojsijeva Zakona, za vrijeme Mojsijeva Zakona te vrijeme milosti koja je došla s Kristom, odnosno evociraju svete oce koji su budno slavili Boga u svakom od tih razdoblja, a molitelji su pozvani nasljedovati njihov primjer na zemlji kako bi jednom sretno prispjeli u slavi s njima i Bogom. Unutar tri nokturna pjeva se devet antifona, psalama, versa, lekcija i responzorija. Za sve navedeno Durand upućuje na ista značenja koja je već prikazao, ali upućuje na prijašnje tumačenje o responzoriju koji označava dobra djela, odnosno konkretno djelo koje treba poduzeti da bi se nauk slušan u lekcijama pravovaljano i pravodobno proveo u djelo (usp. RDO $\mathrm{V}$, 53-54).

U prvom nokturnu govori se dvanaest psalama. Za tih dvanaest psalama predviđene su, kako navodi Durand, tri antifone koje tako psalme dijele u četiri skupine. Prvi nokturn označava vrijeme prije Zakona ili vrijeme prirodnoga zakona. Dvanaest psalama označava dvanaest patrijarha koji su bdjeli nad narodom, okupljali Izabrani narod koji je po njima podijeljen u dvanaest plemena. Ta su plemena kasnije zamijenjena s dvanaest apostola. Skupine od po če-

\footnotetext{
${ }^{49}$ Naziv za dane u tjednu. Nedjelja (lat. dominica) prvi je dan u tjednu, a ferijama pripada ponedjeljak (lat. feria secunda), utorak (lat. feria tertia) i tako do subote (lat. sabbato).
} 
tiri psalma evociraju četiri kardinalne krjeposti: razboritost, jakost, pravednost i umjerenost. Antifone koje čine okvir tim skupinama psalama označuju da se - uz pomoć kardinalnih krjeposti - oblikuje vjera (quadrata est) u Presveto Trojstvo (usp. RDO V,3,18-19). Drugi se nokturn sastoji od tri psalma, nakon kojih slijedi Gloria Patri i antifone prije i poslije svakoga od njih. Ovaj nokturn, koji se moli nedjeljom, prema Durandu bi trebao evocirati uskrsnuće svih pravednika koji su živjeli za trajanja Mojsijeva Zakona (usp. RDO V,3,22). I treći nokturn ima tri psalma, a evocira uskrsnuće svih pravednika koji su živjeli u vremenu milosti koja je došla s Kristom. Antifone koje se govore nakon tih psalama često dolaze s dodatkom Aleluja, koji označava veliku radost koja će nastati kada dođe dan uskrsnuća. Sva tri nokturna zajedno simboliziraju smokvu iz Isusove prispodobe (usp. Lk 13, 7-8), odnosno prema Durandu, tri godine koje je vinogradar tražio za smokvu da ju okopa, pognoji, pa da bi kasnije možda dala rod. Te smokve molitelji su koji trebaju raditi na sebi, kako bi bili vrijedni ući u Kraljevstvo Božje, u suprotnom ih očekuju vječni oganj, odnosno nepovratna odvojenost od Boga (usp. RDO V,3,26).

Nokturni u ferijama sadrže dvanaest psalama koji podsjećaju molitelje da se Bogu treba služiti i u vrijeme dvanaest sati noći. Psalmi se govore dva po dva, a sve kako bi se označilo da dobra djela prati ljubav bez koje ništa nije ispravno. Durand navodi praksu nekih mjesnih Crkvi da nakon psalama noćne službe u ferijama dodaju i Gloria Patri, dok neke zajednice to ne čine. Umetnuta molitva Gloria Patri prema Durandu simbolizira Krista koji je posrednik između neba i zemlje, Boga i ljudi (usp. RDO V,3,27). U ferijama se čitaju tri lekcije, koje označavaju ljude iz tri prije spomenuta razdoblja. Responzoriji koji slijede nakon lekcija označavaju tri teologalne ili bogoslovne krjeposti (vjeru, nadu i ljubav) kojima se slavi Bog u konkretnomu životu svakoga molitelja (usp. RDO V,3,28).

Nakon što je završen i posljednji nokturn, Durand navodi da zvone crkvena zvona i glasno se pjeva Te Deum laudamus. Glasnoća molitve označava otvoreno slavljenje Boga u Crkvi, ali i želju i spremnost da se na Božje poticaje odgovori konkretnim djelima koja će biti svojevrsna ulaznica u vječne radosti. Durand evocira ulomak Lk 15, 8 u kojem se žena raduje zbog pronađene drahme zajedno sa svojim susjedima. Susjedi koji se okupljaju oko žene koja je pronašla drahmu i raduju se s njom označeni su retkom Per singulos dies unutar Te Deum laudamus i zvonjavom zvona (usp. RDO V,3,30). ${ }^{50}$

\footnotetext{
${ }^{50}$ U RDO V, 3,32-37 Durand predstavlja raspored noćne službe koju je unutar svoje reforme predstavio sveti Benedikt iz Nursije. U navedenim brojevima često ponavlja prije donesena značenja pojedinih elemenata oficija, pa stoga taj dio izostavljamo iz analize, štoviše taj dio zahtijeva cjelovitiji pristup unutar odvojenog istraživanja.
} 


\section{ZAKLJUČAK}

Nakon iščitavanja, prikaza i analize izabranih elemenata RDO V, možemo zaključiti da sva tumačenja koja donosi evociraju ekleziološke teme, odnosno povezuje liturgiju, konkretno tijek obreda oficija, s naukom o Crkvi. Neki su autori dosad Duranda povezivali s ekleziologijom samo zbog Prve knjige RDO-a, no sa svakom se dubljom analizom Durand sve više otkriva kao sastavljač liturgijsko-ekleziološkoga traktata prije pojave prvih zaokruženih traktata o Crkvi (lat. de Ecclesia), odnosno prije pojave prvoga takvog traktata Jakova iz Viterba De regimine christiano (1303.).

Durand ekleziološke elemente, razasute po cijelom RDO-u - a posebno smo u ovom istraživanju donijeli primjere tumačenja uz antifone, psalme i tijek noćne službe - uklapa u obrazlaganje o liturgiji koja upućuje na dublji smisao izvan njezina trajanja. Tako liturgija nema svoje ispunjenje u savršenosti forme i sadržaja umjetnoga prostora neke crkve - kao da bi liturgija bila neka vrsta teatra u kojem se može, ali i ne mora, proživjeti katarza - već u liturgiji svakodnevnoga kršćanskog života.

Suvremenom čitatelju mnoga se Durandova donesena tumačenja mogu činiti nerazumljivima, no istraživačima srednjovjekovne liturgije ona daju mogućnost pogledati u um i srce srednjovjekovnoga molitelja liturgijskih tekstova koji su sadržani u brojnim latinskim, a za naše prilike mnogim hrvatskoglagoljskim kodeksima širom svijeta te nam možda otkriti što je za trajanja molitve oficija meditirao njezin molitelj. Na kraju, suvremenim klericima, ali i laicima kojima je božanski časoslov nakon posljednje njegove reforme dostupniji nego ikad prije, Durandova su tumačenja prilika za otkrivanje nove ljepote službene molitve Crkve, koja za klerike nije samo nametnuti teret ili za laike sredstvo kojim se razlikujemo od drugih molitelja, već je mjesto i vrijeme u kojemu se otkriva bit Crkve kao jedne, svete, katoličke i apostolske. Ta je Crkva oduvijek hranjena molitvom, pokretana dobrim djelima koja omogućuje ljubav vjernika prema Bogu i svakom ljudskom biću koje želi prići i sudjelovati u jedinstvenoj ljepoti slavljenja i služenja Bogu u zajednici vjernika. 


\section{IZVORI}

DENZINGER, H. - SCHÖNMETZER, A. 1965. Enchiridion symbolorum, definitionum et declarationum de rebus fidei et morum. Barcinone: Herder.

DURAND, W. 2010. On the Clergy and Their Vestments. A New Translation of Books 2-3 of the Rationale divinorum officiorum. Scranton: University of Scranton Press.

DURAND, W. 2013. Rationale IV. On the Mass and Each Action Pertaining to it. Corpus Christianorum Continuatio in Translation 14. Turnhout: Brepols.

DURAND, W. 2015. Rationale V. Commentary on the Divine Office. Corpus Christianorum Continuatio in Translation 23. Turnhout: Brepols.

DURANTIS, Guilelmus, Mende, Bischof. URL: https://data.cerl.org/thesaurus/cnp01323088 (5. IV. 2019.)

DURANTUS, G. 1995. Rationale divinorum officiorum I-IV. Corpus Christianorum Continuatio Mediaevalis 140. Turnhout: Brepols.

DURANTUS, G. 1998. Rationale divinorum officiorum V-VI. Corpus Christianorum Continuatio Mediaevalis 140A. Turnhout: Brepols.

DURANTUS, G. 2000. Rationale divinorum officiorum VII-VII. Prefatio. Indices. Corpus Christianorum Continuatio Mediaevalis 140B. Turnhout: Brepols.

\section{LITERATURA}

BUIJSSEN, G. 1966. Durandus'Rationale in spätmittelhochdeutscher Übersetzung nach d. Hs. CVP 2765. Assen: Studia theodisca.

BULMAN, J. 2008. The Court Book of Mende and the Secular Lordship of the Bishop. Recollecting the Past in Thirteenth-Century Gévaudan, Toronto - Buffalo - London: University of Toronto Press.

FORCELLA, V. 1869. Iscrizioni delle chiese e d'altri edificii di Roma dal secolo XI fino ai giorni nostri, Volume 1. Rim: Tipografia delle scienze matematiche e fisiche.

HOLMES, S. 2011. William Durandus and a New Approach to the History of Ecclesiology. Ecclesiology 7: 29-49.

HOLMES, S. 2013. The Title of Article 27(26): Cranmer, Durandus and Pope Innocent III. The Journal of Ecclesiastical History 64: 357-364.

HOLMES, S. 2015. Sacred Signs in Reformation Scotland. Interpreting Worship, 14881590. Oxford: Oxford University Press.

MARCHESE, F. T. 2013. Virtues and Vices: Examples of Medieval Knowledge Visualization. Proceedings of the 17th International Conference on Information Visualization: IV'13. Los Alamitos: IEEE Computer Society, 359-365.

ROMANOVA; ROMODANOVSKAJA $2012=$ POMAHOBA, A. A.; РОМОДАНОВСКАЯ, В. А. 2012. Rationale Divinorum officiorum Wilgelmi Durandi в русском переводе конияа XV в. М.-СПб. Москва - Санкт-Петербург: Индрик. [ROMANOVA, A. A.; ROMODANOVSKAJA, B. A. 2012. Rationale Divinorum of- 
ficiorum Wilgelmi Durandi v russkom perevode konca XV v. M.-SPb. Moskva - SanktPeterburg: Indrik.]

SCORCI, P. 2007. Il Messale Romano come strumento della tradizione celebrativa. C. Giraudo (ur.). Il Messale Romano : tradizione, traduzione, adattamento: atti della XXX Settimana di Studio dell'Associazione Professori di Liturgia, Gazzada, 25-30 agosto 2002. Roma: Edizioni Liturgiche, 37-47.

THIBODEAU, T. 1992. William Durand: »Compilator Rationalis«. Ecclesia Orans 9: 97-113.

THIBODEAU, T. 1993. Enigmata Figurarum: Biblical Exegesis and Liturgical Exposition in Durand's Rationale. Harvard Theological Review 86: 65-79.

THIBODEAU, T. 1996. The doctrine of transubstantiation in Durand's Rationale. Traditio 51: 308-317.

THIBODEAU, T. 1997. The influence of canon law on liturgical exposition c. 1100-1300. Sacris erudiri 37: 185-202.

THIBODEAU, T. 2010. The Rationale Divinorum Officiorum of William Durand of Mende. A New Translation of the Prologue and Book One. New York: Columbia University Press.

THOMSON, F. 1994. Greek, Latin and Slavonic - a Medieval Variant of the Theory of Three Pre-eminent Languages in the Late Middle High German Translation of William Durandus' Rationale divinorum officiorum. Together with a Note on the Slavonic Translation of the Latter. Anzeiger für slavische philologie 22: 147-175.

VOGEL, C. 1986. Medieval liturgy: an introduction to the sources. Washington: Pastoral Press.

WHITEHEAD, C. 2003. Columnae... sunt episcopi. Pavimentum... est vulgus: The Symbolic Translation of Ecclesiastical Architecture in Latin Liturgical Handbooks of the Twelfth and Thirteenth Centuries. R. Voaden (ur.). The Medieval Translator. Vol. 8. Turnhout: Brepols, 29-38. 


\section{Summary}

\section{Silvio Košćak}

\section{THEOLOGICAL ALLEGORICAL COMMENTARY OF THE NIGHT OFFICE IN THE LITURGICAL EXPOSITION OF WILLIAM DURAND (1230-1296) WITH EMPHASIS ON THE ANTIPHONS AND PSALMODY}

The author researches symbolism and allegory in the exposition of the Divine Office from the $13^{\text {th }}$ century in the liturgical exposition Rationale divinorum officiorum of William Durand (1230-1296). The fifth book of Rationale, De divinis officiis, explains the order of celebration of the Divine Office according to the Roman Rite. In the first part, the author provides a general overview of the theological and allegorical commentary of liturgical expositions before the $14^{\text {th }}$ century from which the clergy learned about liturgical rites and their ecclesiological meaning. Durand's commentary of liturgical practices is based on the historical, allegorical, tropological, and anagogical exegesis of the Holy Scripture, and its value is in the influence on the theologians and liturgical reforms until the Second Vatican Council. In the second part, the author researches symbolism of the Antiphons and Psalmody in part of the $5^{\text {th }}$ book of Rationale entitled Quid sit officium. In the third part, the author researches meanings that Durand gives to the night office in the part of the $5^{\text {th }}$ book of Rationale entitled De nocturnis.

Keywords: William Durand, Guilielmus Durandus, liturgical exposition, Rationale divinorum officiorum, Antiphons, night office, allegorical exegesis

Silvio Košćak

Legrad (Croatia)

koscak.silvio@gmail.com 